\title{
Validation of a booklet on self-care with the diabetic foot
}

\author{
Validação de cartilha sobre autocuidado com pés de pessoas com Diabetes Mellitus \\ Validación de cartilla sobre autocuidado con pies de personas con Diabetes Mellitus
}

Yara Lanne Santiago Galdino'
ORCID: 0000-0001-9242-1715

Thereza Maria Magalhães Moreira' ORCID: 0000-0003-1424-0649

Antonio Dean Barbosa Marques' ORCID: 0000-0001-8969-1546

Francisca Alexandra Araújo da Silva" ORCID: 0000-0001-6823-0193

'Universidade Estadual do Ceará. Fortaleza, Ceará, Brasil. "Universidade Federal do Ceará, Hospital Universitário Walter Cantídeo. Fortaleza, Ceará, Brasil.

How to cite this article: Galdino YLS, Moreira TMM, Marques ADB, Silva FAA. Validation of a booklet on self-care with the diabetic foot. Rev Bras Enferm [Internet]. 2019;72(2):780-7. doi: http://dx.doi.org/10.1590/0034-7167-2017-0900

\section{Corresponding Author: \\ Antonio Dean Barbosa Marques}

E-mail: antonio-dean@hotmail.com

Submission: 12-28-2017 Approval: 07-16-2018

\section{ABSTRACT}

Objective: to describe the validation of the booklet on self-care with the feet of people with diabetes. Method: methodological study, focusing on the validation of a printed booklet. The content and appearance of the booklet was validated by 23 judges divided into three groups: 11 content and appearance, seven technicians and five of the area of design and marketing. The appearance was validated by 30 people with type 2 Diabetes Mellitus. Results: the judges in the nursing area allowed the validation of material with a Content Validity Index (CVI) of 0.99 , judges in the area of design and marketing with Suitability Assessment of Materials (SAM) of $99.2 \%$ and the target audience with concordance index of $99.4 \%$. Conclusion: the educational booklet proved to be valid and reliable educational material to be used in order to promote compliance with selfcare with the feet of people with Diabetes Mellitus.

Descriptors: Diabetes Mellitus, Type 2; Educational Technology; Diabetic Foot; Validation Studies; Teaching Materials.

\section{RESUMO}

Objetivo: descrever a validação de cartilha sobre o autocuidado com pés de pessoas com diabetes. Método: estudo metodológico, com foco na validação de cartilha impressa. O conteúdo e aparência da cartilha foi validado por 23 juízes divididos em três grupos: 11 de conteúdo e aparência, sete técnicos e cinco da área de design e marketing. A aparência foi validada por 30 pessoas com Diabetes Mellitus tipo 2. Resultados: os juízes na área de enfermagem possibilitaram a validação do material com Índice de Validade do Conteúdo (IVC) total de 0,99, juízes da área de design e marketing com Suitability Assessment of Materials (SAM): 99,2\% e o público-alvo com índice de concordância: 99,4\%. Conclusão: a cartilha educativa mostrou-se material educativo válido e confiável para ser utilizada, a fim de promover a adesão ao autocuidado com os pés de pessoas com Diabetes Mellitus.

Descritores: Diabetes Mellitus Tipo 2; Tecnologia Educacional; Pé Diabético; Estudos de Validação; Materiais de Ensino.

\section{RESUMEN}

Objetivo: describir la validación de cartilla sobre el autocuidado con pies de personas con diabetes. Método: estudio metodológico, con foco en la validación de cartilla impresa. El contenido y apariencia de la cartilla fue validado por 23 jueces divididos en tres grupos: 11 de contenido y aspecto, siete técnicos y cinco del área de diseño y marketing. La apariencia fue validada por 30 personas con Diabetes Mellitus tipo 2. Resultados: los jueces en el área de enfermería posibilitaron la validación del material con Índice de Validez del Contenido (IVC) total de 0,99, jueces del área de diseño y marketing con Suitability Assessment of Materials (SAM): 99,2\% y el público objetivo con índice de concordancia: 99,4\%. Conclusión: la cartilla educativa se mostró material educativo válido y confiable para ser utilizada, a fin de promover la adhesión al autocuidado con los pies de personas con Diabetes Mellitus.

Descriptores: Diabetes Mellitus Tipo 2; Tecnología Educacional; Pie Diabético; Estudios de Validación; Materiales de Enseñanza. 


\section{INTRODUCTION}

In the world and in Brazil, the exponential growth in the number of people with Diabetes Mellitus (DM) has made it a priority disease in global health. The International Diabetes Federation ${ }^{(1)}$ projects that more than 415 million adults worldwide live with the disease today, and by 2040, an estimated 642 million. Brazil ranks $4^{\text {th }}$ among the countries with the highest prevalence of adults with DM and $5^{\text {th }}$ in health expenses, together with the 14.3 million people with the disease.

In diabetes, elevated blood sugar rates increase the risk of developing microvascular, macrovascular, and additional complications, such as retinopathy, cardiovascular disease, and nephropathy, in addition to peripheral neuropathy, which can cause foot ulceration and lead to lower limb amputations ${ }^{(2)}$.

Among these complications, the diabetic foot stands out because it is considered an important collective health problem, to the detriment of the social and economic impact on a global scale. However, the rates of ulceration and amputation vary considerably. This may be due to differences in diagnostic criteria, as well as social, geographical, economic, environmental and access to health services ${ }^{(2)}$. It is estimated that $20 \%$ of the total diabetic population develops foot problems, $5-10 \%$ of foot ulcers and up to $3 \%$ acquire a history of amputations due to the disease ${ }^{(3)}$. Preventive measures could prevent from $44 \%$ to $85 \%$ of amputations $s^{(4)}$. An epidemiological study pointed out that in Ceará State, the number of hospitalizations due to DM for clinical management of other complications is decreasing over the years, however the rate of hospitalization for complicated diabetic foot and consequently limb amputation increases strongly $y^{(5)}$.

The identification and framing of foot-at-risk in the appropriate stratification ${ }^{(2)}$, together with multidisciplinary care through health education to the patient, is shown as a suitable instrument in the prevention of diabetic foot and consequent amputations of the lower extremities, promoting people's sensitization for the development and adoption of skills for self-care and lifestyle enhancement ${ }^{(2,4,6-7)}$.

In order to mediate the process of teaching and learning to the person with endangerment, the nurse makes use of several educational resources in the different scenarios of professional practice, highlighting the use of educational technologies, such as recreational resources for health education ${ }^{(7-8)}$. Effective interventions, such as health education and the provision of educational materials, can improve self-care in individuals with $\mathrm{DM}$, and educational technology is an effective strategy to truly involve the person with DM in their treatment, contributing to the control of blood sugar levels, a whole and in the prevention of complications, such as diabetic foot.

Therefore, there is a need to use scientifically validated educational technologies that can promote the knowledge, assimilation and incorporation of suitable care to prevent complications related to the feet of people with DM and that these technologies are appropriate for their cultural and social reality.

\section{OBJECTIVE}

This study aims to describe the validation of the booklet on self-care with the feet of people with diabetes.

\section{METHOD}

\section{Ethical aspects}

The research was approved by the Research Ethics Committee of the Universidade Estadual do Ceará, for complying with the ethical and legal precepts that govern Resolution $466 / 12^{(9)}$, which deals with guidelines and norms regulating research involving human beings.

\section{Design, place of study and period}

This is a methodological research, which aimed to build and validate an educational technology in booklet format. This type of study has as its research strategy the emphasis on the development, validation and evaluation of tools and research methods ${ }^{(10)}$.

It should be emphasized that the present article focuses on the description of the second stage of the study, focused on the validation process of content, appearance and suitability of the technology produced by judges and target audience held in October 2014.

\section{Population or sample; inclusion and exclusion criteria}

Twenty-three judges were selected for internal validation, divided into three distinct groups: 1) content judges (11 researchers/ Doctors with experience in DM area, educational technologies and/or instrument validation); 2) technical judges (seven nurses with experience in the clinical care of patients with DM); and 3) five judges experienced in professional design and marketing.

The choice of researchers/Doctor judges was made through access and research in the Brazilian Plataforma Lattes, as follows: after accessing the "Plataforma Lattes" website, in the "Curriculum Lattes" window, the "Busca" (Search) option was chosen window "Buscar Currículo Lattes" (Search Curriculum Lattes). The first step was to choose the search mode by clicking on the "Assunto" (Subject) box and in the reserved space was written "Diabetes Mellitus", "Educational health technologies". The "Doctors" base was selected instead of "Other researchers", because it was intended to select researchers with a level of excellence in the subject. Next, filters were applied to the results by "Professional performance", selecting in the "Health sciences" area, the area of "Nursing" and subarea "Public health nursing".

For the selection of technical judges, professionals should have proven knowledge in patient care with DM and were selected by means of snowball sampling, in which, when identifying a subject that fits the criteria for participation in the study, it is requested that suggest other participants ${ }^{(10)}$.

In order to close the panel of judges, five marketing and advertising professionals were also invited to evaluate the suitability of the material for the purpose it proposes. The technique of snowball sampling was adopted.

After making the necessary adjustments in the booklet, through the suggestions made by the specialists, the validation with the target audience was followed. For this stage, 30 patients with a diagnosis of type $2 \mathrm{DM}$ were invited individually, who attended the waiting room of the Centro Integrado de Diabetes e Hipertensão (CIDH - Diabetes and Hypertension Integrated Center) in Fortaleza-Ceará, 
Brazil, during the collection period. They were informed about the research objectives, their risks and benefits, and after accepting the invitation, they were asked to sign the TCLE.

The target audience evaluated the content of the booklet regarding their organization, writing style, appearance and motivation. For the selection of these patients, the inclusion criteria were: age equal to or greater than 18 years, type $2 \mathrm{DM}$ with at least one year of treatment, level of education compatible with reading and understanding of the material, attendance at the unit during the period proposed for data collection and to be available for 20 to 30 minutes to participate in the reading of the booklet and answer the evaluation instrument. We excluded those with cognitive deficits and who had difficulties that impaired the communication and the responses of the instrument.

\section{Study protocol}

The process of constructing and validating the booklet was divided in two moments. In the first phase, the construction of the educational material was based on the items of the Questionário de Adesão ao Autocuidado com os Pés de Pacientes Diabéticos (QPED - Self-Care with Diabetic Patient Feet Questionnaire) $)^{(11)}$ and updated references on DM and diabetic foot.

In the second phase-validation of the educational material, validation of content, appearance and suitability of the booklet was done through its evaluation by judges and, later, with the target population.

Three different instruments were used for the production of data, the first one directed to the Doctor and technical judges, the second one directed to the judges of the area of propaganda and marketing and the third directed to the target audience. The first instrument contained information regarding the objectives, relevance, structure and presentation of the booklet.

The second instrument constituted a checklist to check content, writing style, appearance, motivation and cultural appropriateness of the educational material. It was elaborated based on the American instrument to evaluate the difficulty and convenience of educational materials, called Suitability Assessment of Materials - SAM ${ }^{(12)}$.

The third instrument was divided into two parts, the first with characterization items of the subjects, and the second was the evaluative items of the booklet about organization, writing style, appearance and motivation of the educational material.

\section{Analysis of results and statistics}

The data were analyzed and based on relevant literature on the subject. To validate the educational booklet by the judges of the nursing area, the item and the instruments as a whole must present a Content Validity Index (CVI) of greater than or equal to $0.78^{(13)}$. The items that had a mean lower than the CVI established in the study were modified.

For the validation of the booklet by the marketing and advertising judges, the percentage of scores obtained in the SAM instrument ${ }^{(12)}$. This calculation was performed by means of the total sum of the scores, divided by the total number of items in the questionnaire. The authors consider that, for the material to be considered suitable, it should present a value equal to or greater than $40 \%$ in relation to the total scores.

In the analysis of the data judged by the target audience, the items with a minimum agreement level of $75 \%$ in the positive responses were considered validated. The items with agreement index less than $75 \%$ were considered worthy of change. In a complementary way, the technique of content analysis ${ }^{(14)}$ was used to analyze the speech of the target audience.

\section{RESULTS}

The book entitled "Pé Saudável é Pé Bem Cuidado" (A Healthy Foot is a Well-Cared For Foot) has 40 pages, with dimensions of $150 \times 200 \mathrm{~mm}$, printed in orange and blue, predominantly on coated printing paper of $150 \mathrm{~g} / \mathrm{m}^{2}$, fastened by two clips. The content was summarized in topics: What is diabetic foot?; How to prevent diabetic foot ?; How should I take care of my feet?; Where should I seek help? (Figure 1).

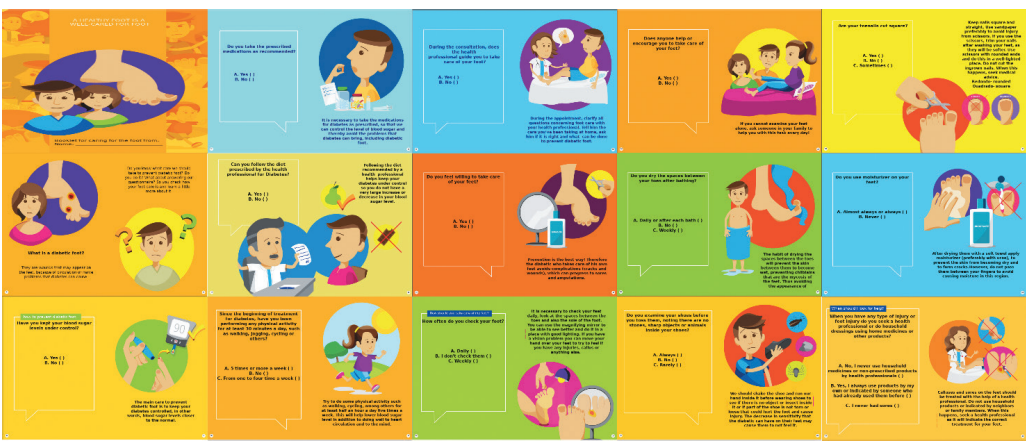

Figure 1 - Validated version of the booklet, Fortaleza, Ceará, Brazil, 2014

Table 1 - Evaluation of content and technical judges regarding the objectives, structure and presentation and relevance of the booklet, Fortaleza, Ceará, Brazil, 2014

\begin{tabular}{|c|c|c|c|c|c|}
\hline Judges & Objectives & $2^{*}$ & $3 * *$ & $4 * * *$ & CVI**** \\
\hline \multirow[t]{6}{*}{$\begin{array}{l}\text { Content } \\
\text { judges }\end{array}$} & $\begin{array}{l}1.1 \text { They are consistent with the needs of patients with DM2 } \\
\text { in relation to self-care with the feet. }\end{array}$ & 01 & 02 & 08 & 0.9 \\
\hline & 1.2 Promote behavior change and attitudes. & 00 & 06 & 05 & 1.0 \\
\hline & $\begin{array}{l}1.3 \text { It can circulate in the scientific environment in the area of } \\
\text { diabetes. }\end{array}$ & 00 & 04 & 07 & 1.0 \\
\hline & Structure and presentation & $2^{*}$ & $3^{* *}$ & $4^{* * *}$ & $C V l^{* * * *}$ \\
\hline & $\begin{array}{l}2.1 \text { The educational material is suitable for the guidance of } \\
\text { patients with DM2 in relation to self-care with the feet. }\end{array}$ & 01 & 01 & 09 & 0.9 \\
\hline & $\begin{array}{l}\text { 2.2 The messages are presented in a clear and objective } \\
\text { manner. }\end{array}$ & 00 & 05 & 06 & 1.0 \\
\hline
\end{tabular}

To be continued 


\begin{tabular}{|c|c|c|c|c|c|}
\hline Judges & Objectives & 2* & $3 * *$ & $4 * * *$ & $\mathbf{C V I} * * * *$ \\
\hline \multirow{14}{*}{$\begin{array}{l}\text { Content } \\
\text { judges }\end{array}$} & 2.3 The information presented is scientifically correct. & 00 & 02 & 09 & 1.0 \\
\hline & 2.4 There is a logical sequence of proposed content. & 00 & 02 & 09 & 1.0 \\
\hline & $\begin{array}{l}2.5 \text { The material is suitable at the sociocultural level of the } \\
\text { proposed target audience. }\end{array}$ & 01 & 04 & 06 & 0.9 \\
\hline & $\begin{array}{l}\text { 2.6 The information is well structured in agreement and } \\
\text { spelling. }\end{array}$ & 01 & 05 & 05 & 0.9 \\
\hline & $\begin{array}{l}\text { 2.7 The style of writing corresponds to the level of } \\
\text { knowledge of the target audience. }\end{array}$ & 03 & 03 & 05 & 0.73 \\
\hline & $\begin{array}{l}2.8 \text { Information on the cover, back cover, acknowledgments } \\
\text { and / or presentation is consistent. }\end{array}$ & 00 & 00 & 11 & 1.0 \\
\hline & 2.9 The illustrations are expressive and sufficient. & 01 & 01 & 09 & 0.9 \\
\hline & 2.10 The number of pages is suitable. & 00 & 01 & 10 & 1.0 \\
\hline & 2.11 The size of the title and topics is suitable. & 02 & 02 & 07 & 0.8 \\
\hline & Relevance & $2^{*}$ & $3^{* *}$ & $4^{* * *}$ & $C \mathrm{Cl}^{* * * *}$ \\
\hline & 3.1 The themes portray the key aspects that should be reinforced. & 00 & 02 & 09 & 1.0 \\
\hline & $\begin{array}{l}\text { 3.2 The material proposes to the patient to acquire } \\
\text { knowledge about the management of self-care with the feet. }\end{array}$ & 00 & 01 & 10 & 1.0 \\
\hline & $\begin{array}{l}\text { 3.3 The material addresses the issues necessary for the } \\
\text { prevention of complications. }\end{array}$ & 00 & 00 & 11 & 1.0 \\
\hline & $\begin{array}{l}3.4 \text { It is suitable for use by any healthcare professional in its } \\
\text { educational activities. }\end{array}$ & 01 & 00 & 10 & 0.9 \\
\hline \multirow{21}{*}{$\begin{array}{l}\text { Technical } \\
\text { judges }\end{array}$} & Objectives & $2^{*}$ & $3^{* *}$ & $4^{* * *}$ & $C V l^{* * * *}$ \\
\hline & $\begin{array}{l}1.1 \text { They are consistent with the needs of patients with DM2 } \\
\text { in relation to self-care with the feet. }\end{array}$ & 00 & 00 & 07 & 1.0 \\
\hline & 1.2 Promotes behavior change and attitudes. & 00 & 00 & 07 & 1.0 \\
\hline & $\begin{array}{l}1.3 \text { It can circulate in the scientific environment in the area of } \\
\text { diabetes. }\end{array}$ & 01 & 00 & 06 & 0.85 \\
\hline & Structure and presentation & & $3^{* *}$ & $4^{* * *}$ & $C V l^{* * * *}$ \\
\hline & $\begin{array}{l}\text { 2.1 The educational material is suitable for the guidance of } \\
\text { patients with DM2 in relation to self-care with the feet. }\end{array}$ & & 00 & 07 & 1.0 \\
\hline & 2.2 The messages are presented in a clear and objective manner. & & 00 & 07 & 1.0 \\
\hline & 2.3 The information presented is scientifically correct. & & 00 & 07 & 1.0 \\
\hline & 2.4 There is a logical sequence of the proposed content. & & 00 & 07 & 1.0 \\
\hline & $\begin{array}{l}2.5 \text { The material is suitable at the sociocultural level of the } \\
\text { proposed target audience. }\end{array}$ & & 01 & 06 & 1.0 \\
\hline & 2.6 The information is well structured in agreement and spelling & & 00 & 07 & 1.0 \\
\hline & $\begin{array}{l}\text { 2.7 The style of writing corresponds to the level of knowledge of } \\
\text { the target audience. }\end{array}$ & & 00 & 07 & 1.0 \\
\hline & $\begin{array}{l}2.8 \text { Information on the cover, back cover, acknowledgments and } \\
\text { or presentation is consistent. }\end{array}$ & & 01 & 06 & 1.0 \\
\hline & 2.9 The illustrations are expressive and sufficient. & & 01 & 06 & 1.0 \\
\hline & 2.10 The number of pages is suitable. & & 00 & 07 & 1.0 \\
\hline & 2.11 The size of the title and topics is suitable. & & 00 & 07 & 1.0 \\
\hline & Relevance & & $3^{* *}$ & $4^{* * *}$ & $C V I^{* * * *}$ \\
\hline & 3.1 The themes portray the key aspects that should be reinforce & & 00 & 07 & 1.0 \\
\hline & $\begin{array}{l}\text { 3.2 The material proposes to the patient to acquire knowledge } \\
\text { about the management of self-care with the feet. }\end{array}$ & & 00 & 07 & 1.0 \\
\hline & $\begin{array}{l}\text { 3.3 The material addresses the issues necessary for the preventic } \\
\text { of complications. }\end{array}$ & & 02 & 05 & 1.0 \\
\hline & $\begin{array}{l}3.4 \text { It is suitable for use by any health professional in its } \\
\text { educational activities. }\end{array}$ & & 00 & 07 & 1.0 \\
\hline
\end{tabular}

Notas: Escala Likert: 2-Parcialmente Adequado*, 3-Adequado**, 4-Totalmente Adequado; IVC= Índice de Validade de Conteúdo.
Table 1 presents the Content Validity Index (CVI) of content judges and technicians regarding the objectives, structure and presentation and relevance of the booklet.

In the validation of content, regarding the objectives of the booklet, the CVI was 0.97 . Only one judge classified 1.1 (consistency of objectives with the needs of patients with DM2 in relation to foot care) as partially suitable. The specialist suggested a change where in the initial version there was only reference to the oral medication, because some patients make use of insulin in their treatment. Therefore, the design was requested to add the insulin bottle with the syringe in this illustration.

Subsequently, the judges of content evaluated the booklet as to its structure and presentation, with CVI of 0.92. In the initial version of the booklet, three judges questioned the use of the terms "hypoglycemia" and "diabetic coma" (page 15 of the booklet), as well as the word "macerated" (pages 27 and 33), claiming that most patients might not know such concepts. The suggestions of the experts were followed. The word "macerated" was replaced by the word "wet" (page 27) and the other inferences to the terms were removed from the book without, however, prejudicing its final message.

Another judge suggested rephrasing a question (page 14) and we heeded his suggestion. Therefore, where before it was written:"Can you follow the diet prescribed by the health professional for Diabetes?"Now it is written:"Can you follow the diabetes diet prescribed by the health professional?". The words "put it on" and "pass it on" (29 and 33) were corrected after the same specialist, since they were written without correct accent.

On page 21 of the booklet, one of the content judges 
suggested that the quote "diabetics taking care of their feet" would have a better connotation if it were written "diabetics who take care of their own feet". The suggestion was accepted and we made the modification in the final version of the booklet.

With regard to the evaluation of the relevance of the booklet, it was verified that all items were validated, and that the CVI referring to this question was 0.97 . The $\mathrm{CVI}$ of the booklet by the Doctor judges was 0.99 .

In addition to the validation carried out with 11 Doctor judges, the first version of the booklet was evaluated by seven technical judges. The technical judges validated all items of the objectives of the booklet and the CVI for this category was 0.95. Two judges suggested adding something about footwashing and one of them suggested removing the oil-on-the-feet orientation, recommending only the use of the moisturizer.

The two suggestions were followed and the text of the booklet was changed (page 33). Where the initial text was "We must apply moisturizer or oil daily on the feet to prevent the skin from drying out and form cracks, however, do not pass it between the fingers, not to cause moisture in that region and macerate the skin", and now is: "We must wash our feet daily with water and soap. And then, dry them with a soft towel, apply moisturizer (preferably with urea), to prevent the skin from drying out and forming cracks. However, do not pass it between your fingers, to avoid causing moisture in this region".

The booklet was also validated as to its structure and presentation by the group of technical judges. The total CVI of this item was 1.0. That is, the judges considered all items as "suitable" or "totally suitable".

One of the judges suggested the idea of including people with DM who were visually impaired so that they could examine their feet, passing their hands over them, as a way of verifying the presence of possible changes. The suggestion was considered. The text (page 23 of the initial version of the booklet) was "It is necessary to examine your feet daily, look at the spaces between the fingers and also the sole of the foot. See if there is any sore or crack. You can use a magnifying mirror to be able to see better and do it in a place with good lighting", now is: "It is necessary to examine your feet daily, look at the spaces between the toes and also the sole of the foot. See if there is any sore or crack. You can use a magnifying mirror to be able to see better and do so in a well-lit location. If you have a vision problem, you can move your hand over your feet to try to feel if you have any injuries, callus or anything else".

In terms of relevance, the CVI was 1.0, since the judges considered all the items as "suitable" or"totally suitable". The total CVI of the booklet for this group of judges was 0.99 .

The study was continued with the validation of the technology with the
Table 2 - Evaluation of judges in the area of design and marketing regarding the suitability of the booklet, Fortaleza, Ceará, Brazill, 2014

\begin{tabular}{ccccccccccccccc}
\hline Judge & 1.1 & 1.2 & 1.3 & $\mathbf{2 . 1}$ & $\mathbf{2 . 2}$ & $\mathbf{2 . 3}$ & $\mathbf{3 . 1}$ & $\mathbf{3 . 2}$ & $\mathbf{4 . 1}$ & $\mathbf{4 . 2}$ & $\mathbf{4 . 3}$ & $\mathbf{5 . 1}$ & $\mathbf{5 . 2}$ & SAM* Score \\
\hline 1 & 2 & 2 & 2 & 2 & 2 & 2 & 2 & 2 & 2 & 2 & 2 & 2 & 2 & 26 \\
2 & 2 & 2 & 2 & 2 & 2 & 2 & 2 & 2 & 2 & 2 & 2 & 2 & 2 & 26 \\
3 & 2 & 2 & 2 & 2 & 2 & 2 & 2 & 2 & 2 & 2 & 2 & 2 & 2 & 26 \\
4 & 2 & 2 & 2 & 2 & 2 & 2 & 1 & 2 & 2 & 2 & 2 & 2 & 2 & 25 \\
5 & 2 & 2 & 2 & 2 & 2 & 2 & 1 & 2 & 2 & 2 & 2 & 2 & 2 & 25 \\
\hline
\end{tabular}

Note: $S A M=$ Suitability Assessment of Materials*.

professionals of design and marketing. By means of the instrument, this group of specialists evaluated the suitability of the technology (items 1.1 to 1.3 ), language (items 2.1 to 2.3 ), graphic illustrations (items 3.1 and 3.2), motivation (items 4.1 to 4.3 ) and cultural appropriateness (items 5.1 and 5.2).

The educational booklet was considered suitable by the entire group of judges, since all of them evaluated the booklet with SAM 25 or 26, thus exceeding the minimum required 10 points, with SAM of $99.2 \%$, which can be visualized in Table 2 .

Finalizing the validation of the content, appearance and suitability of the booklet, the booklet was submitted to the evaluation by the target audience. To accomplish this stage, we initially presented the objectives of the study and the relevance of the evaluation of the patients for the validation and improvement of the quality of the booklet and then they were invited to participate in the research. Of the 30 patients, half $(15 ; 50 \%)$ were aged $\geq 60$ years old, predominantly female (16;53\%), married majority $(18 ; 60 \%)$, large majority with study time $\geq$ ten years 18 ; $60 \%)$ and half with oral drug therapy $(15 ; 50 \%)$.

Table 3 - Evaluation of the target audience regarding the organization, writing style, appearance and motivation of the booklet, Fortaleza, Ceará, Brazil, 2014

\begin{tabular}{|c|c|c|c|c|c|c|}
\hline \multirow[t]{2}{*}{ Variables } & \multicolumn{2}{|c|}{$\begin{array}{l}\text { Positive } \\
\text { Answers }\end{array}$} & \multicolumn{2}{|c|}{$\begin{array}{l}\text { Negative } \\
\text { Answers }\end{array}$} & \multicolumn{2}{|c|}{$\begin{array}{l}\text { Impartial } \\
\text { Answers }\end{array}$} \\
\hline & $\mathbf{n}$ & $\%$ & $\mathbf{n}$ & $\%$ & $\mathbf{n}$ & $\%$ \\
\hline \multicolumn{7}{|l|}{1 Organization (yes/ no/ I do not know) } \\
\hline 1.1 Did the cover catch your eye? & 29 & 96.7 & 00 & - & 01 & 3.3 \\
\hline 1.2 Is the content sequence suitable? & 30 & 100 & 00 & - & 00 & - \\
\hline 1.3 Is the structure of the educational booklet organized? & 30 & 100 & 00 & - & 00 & - \\
\hline \multicolumn{7}{|l|}{2 Writing style } \\
\hline $\begin{array}{l}\text { 2.1 Regarding the understanding of the sentences, they are: } \\
\text { easy to understand / hard to understand / I do not know }\end{array}$ & 30 & 100 & 00 & - & 00 & - \\
\hline 2.2 The content is: clear / confusing / I do not know & 30 & 100 & 00 & - & 00 & - \\
\hline 2.3 The text is: interesting / uninteresting / I do not know & 30 & 100 & 00 & - & 00 & - \\
\hline \multicolumn{7}{|l|}{3 Appearance } \\
\hline 3.1 The illustrations are: simple / complicated / I do not know & 30 & 100 & 00 & - & 00 & - \\
\hline $\begin{array}{l}\text { 3.2 Do the illustrations complement the text? } \\
\text { yes/ no/ I do not know }\end{array}$ & 30 & 100 & 00 & - & 00 & - \\
\hline $\begin{array}{l}3.3 \text { Do the pages or sections seem organized? } \\
\text { yes/ no/ I do not know }\end{array}$ & 30 & 100 & 00 & - & 00 & - \\
\hline \multicolumn{7}{|l|}{4 Motivation (yes/ no/ I do not know) } \\
\hline $\begin{array}{l}4.1 \text { In your opinion, any patient with DM who read this } \\
\text { booklet will understand what it is about? }\end{array}$ & 29 & 96.7 & 00 & - & 01 & 3.3 \\
\hline 4.2 Did you feel motivated to read the booklet until the end? & 29 & 96.7 & 01 & 3.3 & 00 & - \\
\hline $\begin{array}{l}\text { 4.3 Does the educational material address the issues necessary for } \\
\text { patients with DM to take proper care of their feet? }\end{array}$ & 30 & 100 & 00 & - & 00 & - \\
\hline $\begin{array}{l}\text { 4.4 Has the educational booklet suggested you to act or think } \\
\text { about caring for your feet? }\end{array}$ & 30 & 100 & 00 & - & 00 & - \\
\hline
\end{tabular}


For validation, the corrected and printed version of the booklet was delivered individually to the patient, and only after the material was handled and read were they asked to respond to the validation instrument. All items inherent to the organization, writing style, appearance and motivation of the booklet were considered validated by the target audience, as they reached an agreement rate of more than 75\%, according to Table 3 .

One participant pointed out "in part", regarding the attractiveness of the cover, as well as the motivation to use the booklet related to the understanding of it by any patient with DM. However, he made no suggestion or comment on these aspects. Another patient answered not to be motivated to read the booklet until the end and justified this lack of motivation due to the retinopathy, probably caused by the disease, since this patient referred diagnosis of the disease more than ten years ago.

In addition, all items had a positive evaluation, unanimously. The representatives of the target audience were asked to make suggestions and to express their opinion about the educational booklet. No suggestion was made by the participants. However, when answering the question "Generally speaking, what did you think of the booklet?" Patients' answers gave rise to three categories of analysis, according to the similarity of the elements presented in the speeches: explanatory, important and appropriate (Chart 1).

At the end, the target audience achieved a concordance index of $99.4 \%$.

Chart 1 - Evaluation of the booklet by the target audience, according to the unit of meaning and corresponding speeches, Fortaleza, Ceará, Brazil, 2014

\begin{tabular}{|c|l|}
\hline Unit of Meaning & \multicolumn{1}{c|}{ Speeches } \\
\hline Explanatory & $\begin{array}{c}\text { The sentences are very easy to understand. (P. 1, 2, 5, } \\
\text { 12, 29) } \\
\text { Spelling is easy to understand. (P. 16) } \\
\text { The topic is clear. (P. 19, 27) } \\
\text { It's very interesting and explanatory. A person who is } \\
\text { reading will understand quickly. (P. 20) } \\
\text { The content is in an easy and accessible language, with } \\
\text { no complications of interpretation. (P. 25) } \\
\text { Iliked the pictures, the well explained and well readable } \\
\text { words. (P. 28) } \\
\text { Even those who cannot read, if they look at it, they can } \\
\text { understand. (P. 30) }\end{array}$ \\
\hline Important & $\begin{array}{l}\text { There were things in the book that I never imagined I } \\
\text { needed to know. (P. 3) } \\
\text { Very useful and easy to understand, it helped a lot } \\
\text { about the care we should take with our feet. (P. 8) } \\
\text { The subject that the booklet brings is important both } \\
\text { for the patient and for the relatives who are close to } \\
\text { him. (P. 11) } \\
\text { It is an incentive for the person to take better care of } \\
\text { himself. (P. 17) } \\
\text { It induces people to do things they would not to. (P. 18) } \\
\text { Ithink it is an interesting material for all those who live } \\
\text { with this disease. (P. 22) }\end{array}$ \\
\hline Suitable & $\begin{array}{l}\text { It is well developed. Paper is great and easy to read. (P. 4) } \\
\text { Very good. The booklet is great.. (P. 6, 9, 13, 21, 23) } \\
\text { Interesting ... the letters are a good size so that we can } \\
\text { see well. (P. 7) } \\
\text { Ifound it wonderful. (P. 10) } \\
\text { The material has good quality and a very good } \\
\text { visualization. (P. 14) } \\
\text { It is suitable for what is determined to clarify. (P. 15) } \\
\text { The illustrative part is great. (P. 24, 26) } \\
\text { It is very complete. (P. 29) }\end{array}$ \\
\hline
\end{tabular}

\section{DISCUSSION}

The use of validated educational technologies gives a greater degree of reliability to the teaching-learning process, narrows the communication of health care, validates the safety of the presented guidelines and enhances the degree of coherence of the information in answering the proposed objective, corroborating as mediator of relationship between the target audience and the health professional ${ }^{(15)}$.

The process of constructing an educational material for people with DM involves scientific knowledge and its content must be validated according to the consensus of experts for requesting multidisciplinary evaluation and critical analysis by the patients ${ }^{(16)}$.

It should be emphasized that careful and systematic examination by professionals of different specialties is fundamental to improve quality. It is recommended to include design professionals and advertising layout to better match the educational material employed to patients ${ }^{(17)}$.

The content of educational resources should consider the characteristics of the target population, besides socioeconomic and environmental conditions to ensure positive behavior change ${ }^{(6)}$.

The vocabulary used in printed materials should be consistent with the intended message and with the target audience for information, complex words and technical terminologies should be avoided and their reading should be easy, inviting and understandable $\mathrm{e}^{(16,18)}$.

Another important point is the use of images/illustrations to capture the attention of the target audience, and this educational strategy increases the knowledge, as well as can infer in the compliance with drugs, diet among patients with type 2 DM, even with low literacy ${ }^{(19)}$. Therefore, these should be appropriate to the theme, in order to provide understanding and recall of the text, elucidating and reinforcing the information seizure, causing the reader's decision to continue reading ${ }^{(20)}$.

In this context, patients with type 2 DM require the ability to perform self-care by requesting complex treatments and appropriate health behaviors, being a key factor. Faced with such complexity, we have the relevance of functional literacy in health ${ }^{(21)}$.

Thus, it is necessary to use illustrations that punctually portray the objective of the material. This evaluation was relevant to evaluate the educational material for the purpose of provoking/ sensitizing the compliance of people with DM in relation to selfcare with the feet, preventing the diabetic foot outcome. It stands out the testimony expressed by P. 30, when he stated that Even those who cannot to read, if they keep looking at the booklet, they can understand. This speech translates that educational technology is accessible to patients with different levels of readability.

\section{Study limitations}

The limiting factor of this study is the lack of clinical validation. It is intended to carry out in a later study, comparing with other technological resources and making the resource available in different formats.

\section{Contributions to Nursing, Health or Public Policy}

The validation process by different groups of judges and by the target audience allowed the elaboration of an educational resource 
centered on the real and potential peculiarities of people with diabetic foot. Thus, it is expected that the educational booklet can contribute positively to the compliance of self-care practices with the feet of patients with DM, and that it impacts on the reduction and occurrence of ulcers and amputations of lower limbs.

\section{CONCLUSION}

The nursing judges contributed to the adaptation and improvement of the technology by adding knowledge and values to its final version. The engagement of professionals in the area of design and marketing in the process of validation of the technology allowed the positive evaluation of the suitability of the material with emphasis to illustrations and diagrammations.

The participation of people with DM of different levels of education made it possible to evaluate that the technology developed is suitable in relation to the clarity and comprehension of the language and the illustrations, and the content considered relevant for the transmission of knowledge and awareness to the promotion of behavior change.

\section{REFERENCES}

1. International Diabetes Federation. IDF Diabetes. $7^{a}$ ed. Belgium; 2015.

2. International Diabetes Federation. Clinical Practice Recommendation on the Diabetic Foot: A guide for health care professionals: International Diabetes Federation, 2017.

3. Alexiadou K, Doupis J. Management of diabetic foot ulcers. Diabetes Ther [Internet]. 2012 [cited 2017 Sep 18];3:4. Available from: https:// doi.org/10.1007/s13300-012-0004-9

4. Ministério da Saúde (BR), Secretaria de Atenção à Saúde, Departamento de Atenção Básica. Manual do pé diabético: estratégias para o cuidado da pessoa com doença crônica. Brasília; 2016.

5. Marques ADB, Silva LMS, Moreira TMM, Torres RA. Association between hospitalization due to diabetes mellitus and diabetic foot amputation. Enferm Glob [Internet]. 2018 [cited 2019 Mar 15];17(51):258-66. Available from: http://dx.doi.org/10.6018/eglobal.17.3.286181

6. Marques ADB, Texeira AKS, Moreira TMM, Carvalho REFL, Fialho AVM, Chaves EMC. Nursing interventions for the prevention of foot ulcers in patients with diabetes: an integrative review. Int Arch Med [Internet]. 2017 [cited 2017 Sep 17];10(163):1-8. Available from: https://doi. org/10.3823/2433

7. Menezes LCG, Guedes MVC, Moura NS, Oliveira RM, Vieira LA, Barros AA. Educational strategies for diabetic people at risk for foot neuropathy: synthesis of good evidence. Rev Eletr Enf [Internet]. 2016 [cited 2017 Sep 18];18:e1197. Available from: http://dx.doi. org/10.5216/ree.v18.40281

8. Moura DJM, Moura NS, Guedes MVC. Development of a booklet on insulin therapy for children with diabetes mellitus type 1. Rev Bras Enferm [Internet]. 2017 [cited 2017 Oct 04];70(1):3-10. Available from: http://www.scielo.br/pdf/reben/v70n1/en_0034-7167reben-70-01-0007.pdf

9. Conselho Nacional de Saúde (BR). Resolução n 466, de 12 de dezembro de 2012. Diretrizes e Normas Regulamentadoras de Pesquisas Envolvendo Seres Humanos. Diário Oficial União: República Federativa do Brasil; 2013. Jun 13, Seção 71: p. 59.

10. Polit DF, Beck CT. Fundamentos de Pesquisa em enfermagem: avaliação de evidências para as práticas da enfermagem. 7th ed. Porto Alegre: Artmed; 2011.

11. Silva FAA. Adesão ao autocuidado com os pés em diabéticos: construção e validação de um instrumento avaliativo [Thesis]. Fortaleza (CE): Universidade Estadual do Ceará, Universidade, Programa de Pós-Graduação em Saúde Coletiva; 2014.

12. Sousa CS, Turrini RNT, Poveda VB. Translation and adaptation of the instrument "suitability assessment of materials" (sam) into portuguese. Rev Enferm UFPE on line. [Internet]. 2015 [cited 2017 Sep 18];9(5):7854-61. Available from: https://doi.org/10.5205/ reuol.6121-57155-1-ED.0905201515

13. Alexandre NMC, Coluci MZO. [Content validity in the development and adaptation processes of measurement instruments]. Ciênc Saude Colet [Internet]. 2011 [cited 2017 Oct 02];16(7):3061-8. Available from: http://dx.doi.org/10.1590/S1413-81232011000800006 Portuguese.

14. Bardin L. Análise de conteúdo. 3a ed. São Paulo: Edições 70; 2011.

15. Albuquerque AFLL, Pinheiro AKB, Linhares FMP, Guedes TG. Technology for self-care for ostomized women's sexual and reproductive health. Rev Bras Enferm [Internet]. 2016 [cited 2017 Oct 02];69(6):1099-106. Available from: http://dx.doi.org/10.1590/0034-7167-2016-0302

16. Aquino JA, Baldoni AO, Oliveira CL, Figueiredo RC, Cardoso CS, Pereira ML et al. Educational booklet on diabetes construction and content validation. Semina Ciênc Biol Saude [Internet]. 2016 [cited 2017 Oct 02];37(1):77-82. Available from: https://doi. org/10.5433/1679-0367.2016v37n1p77

17. Oliveira SC, Lopes MVO, Fernandes AFC. Development and validation of an educational booklet for healthy eating during pregnancy. Rev Lat Am Enfermagem [Internet]. 2014 [cited 2016 Sep 10];22(4):611-20. Available from: https://doi.org/10.1590/0104-1169.3313.2459

18. Paula CLM, Santos EVL, Maia PCGGS, Gouveia Filho PS, Sousa MNA. [Quality of life elderly participants of a group of coexistence in the municipality of são mamede - PB]. Rev Bras Educ Saude [Internet]. 2016 [cited 2017 Oct 17];6(2):1-7. Available from: https://doi. org/10.18378/rebes.v6i2.4018 Portuguese. 
19. Odajima Y, Kawaharada M, Wada N. Development and validation of an educational program to enhance sense of coherence in patients with diabetes mellitus type 2. Nagoya J Med Sci [Internet] 2017 [cited 2017 Oct 17];79(3):363-74. Available from: https://doi.org/10.18999/ nagjms.79.3.363

20. Passamai MPB, Sampaio HAC, Lima JWO. Letramento funcional em saúde de adultos no contexto do Sistema Único de Saúde. Fortaleza, EdUECE; 2013. 25p.

21. Sampaio HAC, Carioca AAF, Sabry MOD, Santos PM, Coelho MAM, Passamai MPB. [Health literacy in type 2 diabetics: associated factors and glycemic control]. Ciênc Saude Colet [Internet]. 2015 [cited 2017 Oct 19];20(3):865-74. Available from: https://doi.org/10.1590/141381232015203.12392014 Portuguese. 